NBER WORKING PAPER SERIES

TARIFF INCIDENCE:

EVIDENCE FROM U.S. SUGAR DUTIES, 1890-1930

Douglas A. Irwin

Working Paper 20635

http://www.nber.org/papers/w20635

\author{
NATIONAL BUREAU OF ECONOMIC RESEARCH \\ 1050 Massachusetts Avenue \\ Cambridge, MA 02138 \\ October 2014
}

I wish to thank Maha Malik and Clare Snyder for excellent research assistance. I am also indebted to Alan Dye for providing important background information on the Cuban sugar industry, Jim Poterba for helpful discussions and references, and seminar participants at Dartmouth, Brandeis, MIT, LSE, Harvard, and Vanderbilt for very helpful discussions. The views expressed herein are those of the author and do not necessarily reflect the views of the National Bureau of Economic Research.

NBER working papers are circulated for discussion and comment purposes. They have not been peerreviewed or been subject to the review by the NBER Board of Directors that accompanies official NBER publications.

(C) 2014 by Douglas A. Irwin. All rights reserved. Short sections of text, not to exceed two paragraphs, may be quoted without explicit permission provided that full credit, including $(\mathbb{C}$ notice, is given to the source. 
Tariff Incidence: Evidence from U.S. Sugar Duties, 1890-1930

Douglas A. Irwin

NBER Working Paper No. 20635

October 2014

JEL No. F13,F14,N11,N12

\begin{abstract}
$\underline{\text { ABSTRACT }}$
Direct empirical evidence on whether domestic consumers or foreign exporters bear the burden of a country's import duties is scarce. This paper examines the incidence of U.S. sugar duties using a unique set of high-frequency (weekly, and sometimes daily) data on the landed and the duty-inclusive price of raw sugar in New York City from 1890 to 1930, a time when the United States consumed more than 20 percent of world sugar production and was therefore plausibly a "large" country. The results reveal a striking asymmetry: a tariff reduction is immediately passed through to consumer prices with no impact on the import price, whereas about 40 percent of a tariff increase is passed through to consumer prices and 60 percent borne by foreign exporters. The apparent explanation for the asymmetric response is the asymmetric response of demand: imports collapse upon a tariff increase, but do not surge after a tariff reduction.
\end{abstract}

Douglas A. Irwin

Department of Economics

Dartmouth College

Hanover, NH 03755

and NBER

douglas.irwin@dartmouth.edu 


\section{Tariff Incidence: Evidence from U.S. Sugar Duties, 1890-1930}

\section{Introduction}

One of the classic questions about international trade policy concerns the incidence of import duties. The classical economists generally assumed that consumers paid the tariff in the form of higher domestic prices. Bickerdike (1906) was among the first to note that a country might be able to shift the burden of its import tariffs onto foreign suppliers by forcing them to reduce their export price. Provided the elasticity of foreign export supply is not perfectly elastic, Bickerdike showed that some portion of an importing country's tariff would be absorbed by foreign exporters, leading him to formulate the elasticity condition for the "optimal" tariff on imports.

While the theory of tariff incidence is well developed, relatively few studies provide direct empirical evidence on whether changes in a country's tariffs affect its import prices. Winkelmann and Winkelmann (1998) find that New Zealand's extensive tariff reductions in the mid-1980s did not affect the country's import prices, although few would believe that New Zealand is a good example of a "large" country with monopsony power that could shift the burden of its import duties onto foreign suppliers. The United States is more plausibly a large country, but even here evidence is scarce. ${ }^{1}$ Feenstra (1989) studied the impact of import duties on Japanese compact trucks and heavyweight motorcycles in the 1980s and concluded that the domestic price of motorcycles increased by the full extent of the tariff and the domestic price of trucks increased by 60 percent of the tariff, implying that 40 percent of the duty was absorbed by

\footnotetext{
${ }^{1}$ Kreinin (1961) examined U.S. tariff changes resulting from the 1955 General Agreement on Tariffs and Trade (GATT) negotiations. He found that about half of the tariff reductions were passed through to consumer prices and about half absorbed by exporters in the form of higher export prices, but the use of annual data and the inability to control for other factors makes this conclusion quite speculative.
} 
foreign exporters. These two papers are the only ones that I am aware of that directly observe what happens to prices when tariff rates are changed.

This scarcity of evidence has led economists to look at indirect ways of assessing tariff incidence. One method is to estimate elasticities of foreign export supply facing an importing country with the view that, if those elasticities are less-than-perfectly elastic, import prices might fall if a tariff were imposed. ${ }^{2}$ For example, Broda, Limão, and Weinstein (2008) estimate thousands of export supply elasticities and show that import duties in 15 developing countries are negatively correlated with those elasticities; i.e., higher duties were imposed on goods where export supply is relatively inelastic. While this cross-sectional evidence is consistent with the optimal tariff argument, they present no evidence on whether the tariffs actually improved the terms of trade or their removal would deteriorate the terms of trade. ${ }^{3}$

Beyond these efforts, however, there is a notable lack of empirical (as opposed to computational) evidence on the incidence of tariffs. Economists have studied the impact of exchange rate changes, antidumping duties, and preferential tariff reductions on import prices, but these cases would not be expected to have the same impact as a permanent, across-the-board change in import duties on all sources of supply. For example, exchange rate fluctuations are often temporary whereas tariff changes are more permanent, complicating a comparison between the two (Nakamura and Zerom 2010), while antidumping duties and preferential tariff reductions

\footnotetext{
${ }^{2}$ Magee and Magee (2008) use estimated trade elasticities along with data on market shares to conclude that the United States has little scope to influence its terms of trade through policy measures.

${ }^{3}$ In fact, it seems unlikely that most of the countries in their sample, such as Belarus, Latvia, Lebanon, and Lithuania, could influence the price of their imports, or that Algeria and Paraguay have more market power than China and Russia and have optimal tariffs in the range of 200-300 percent. Furthermore, Nicita, Olarreaga, and Silva (2014) also estimates a large number of export supply elasticities but find virtually no correlation between their estimates and those of Broda, Limão and Weinstein (the correlation is 0.03). The median optimal tariff is 4 percent in Nicita et al as opposed to the 200-300 percent in Broda et al. Ludema and Mayda (2014) take a similar approach to Broda, Limão and Weinstein.
} 
usually apply to only a small number of suppliers and produce trade diversion (Chang and Winters 2002).

This paper contributes to our understanding of tariff incidence by employing a unique data set during a unique historical period. The paper focuses on a single homogeneous good (raw cane sugar, 96 degrees centrifugal), for which there is excellent high frequency data (weekly, sometimes daily) on both sides of the tariff wall (the landed import price and the postduty market price) in a single location (New York City). The period under consideration is also one in which the United States enacted large, unilateral tariff changes that took place abruptly without any phase-in period. Furthermore, the United States accounted for 20 to 25 percent of world consumption of sugar and might therefore be expected to have had significant influence on the world price of sugar. (The main foreign supplier of cane sugar, Cuba, sent nearly all of its sugar to the United States.)

This paper examines the incidence of the sugar duties by looking at the response of the domestic and import price of sugar at the time of the changes in those duties, much like the public finance literature's analysis of the impact of sales taxes on consumer prices (Poterba 1996, Besley and Rosen 1999). The weekly (and daily) data allow us to examine the changes in domestic and landed import prices of an identical product in a window around every tariff change; less precise monthly data are also used as a robustness check and to control for other covariates.

The results reveal a pronounced asymmetry in tariff changes: a tariff reduction is immediately and fully passed through to the domestic price with no apparent impact on the import price, whereas a tariff increase is shared between a higher domestic price and a lower import price. The apparent explanation for this asymmetric price response is an asymmetric 
demand response: tariff reductions spurred only a slight, immediate increase in demand because purchasers knew the lower prices would be in effect for the foreseeable future, but tariff increases usually triggered a surge of buying in the weeks prior to the higher duties taking effect, followed by a severe collapse in purchases for many weeks thereafter.

\section{The Sugar Industry and Import Tariffs}

A key issue in determining the impact of any tax on prices is obtaining accurate price data on the good being taxed. One problem in studying tariff incidence is that import prices are often calculated as unit values at a fairly high level of aggregation, meaning that the unit value might include many different products each of which might have a different tariff rate associated with it. This makes it difficult to identify the impact of a particular tariff change on import prices (or domestic prices, which suffer from the same problem).

This paper overcomes this difficulty by focusing on a very specific homogeneous product - raw sugar, $96^{\circ}$ centrifugal, the standard commodity grade of traded sugar. ${ }^{4}$ Willett $\&$ Gray's Weekly Statistical Sugar Trade Journal presents weekly data on the landed (cost and freight) price of imported $96^{\circ}$ centrifugal sugar in New York City and the market price of $96^{\circ}$ centrifugal sugar in New York City once it had cleared customs. This high frequency data on an identical product in one location on both sides of the tariff wall make it possible to examine tariff incidence since we know the specific day that a tariff change takes effect.

Sugar Trade and Processing

\footnotetext{
${ }^{4}$ This refers to the standard grade of raw sugar which is 96 percent sucrose and 4 percent water and other impurities. Raw sugar is melted, purified, and crystallized into refined sugar, which is 100 percent sucrose.
} 
Raw sugar is extracted from sugar cane or sugar beets and then refined to become pure granulated sugar, which is sold to households and food manufacturers. The United States produces some cane sugar (in Louisiana and Hawaii) and some beet sugar (in the northern Midwest), but not enough to satisfy domestic demand. Therefore, the United States has long been a major importer of raw cane sugar for domestic refining. In the late nineteenth century, the sugar refining industry was largely located in New York, with some residual refining capacity in Boston, Philadelphia, and Baltimore. Hence, whether it came from Louisiana or Cuba or other sources of supply, most raw sugar was shipped to New York where plants were located next to docks for easy unloading and processing.

The United States was a large player in the world sugar market. As Figure 1 shows, the United States consumed about 20 to 25 percent of the world's production of sugar in the late nineteenth and early twentieth century.

\section{Figure 1: U.S. Consumption of Sugar as Share of World Production}

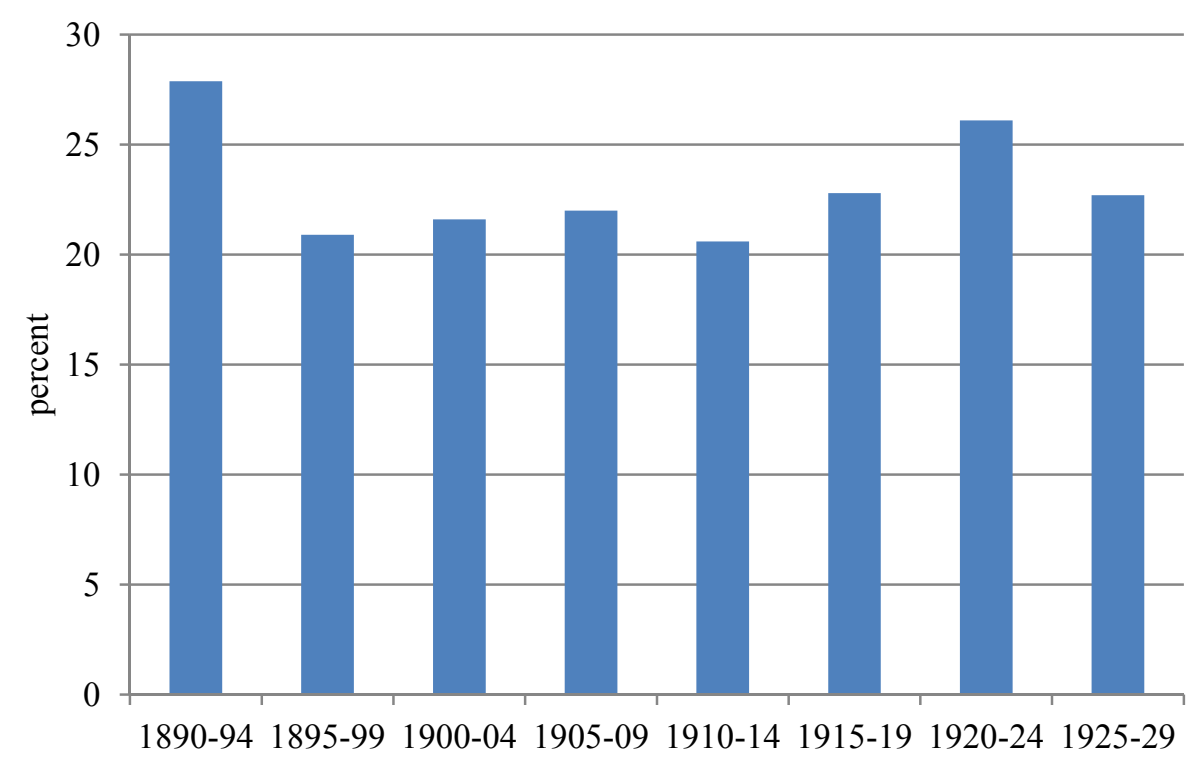

Source: Statistical Abstract of the United States (1932, 653). 
A substantial portion of this sugar was imported and the main source of supply was Cuba. Figure 2 shows that Cuba supplied about a third of the raw sugar consumed by the United States. Furthermore, the United States might have had some monopsony power with respect to Cuban sugar. In the 1890s, Cuba sent more than 85 percent of its sugar exports to the United States; after 1900, about 99 percent of Cuba's sugar was destined for the United States.

Figure 2: Sources of Supply of U.S. Sugar Consumption

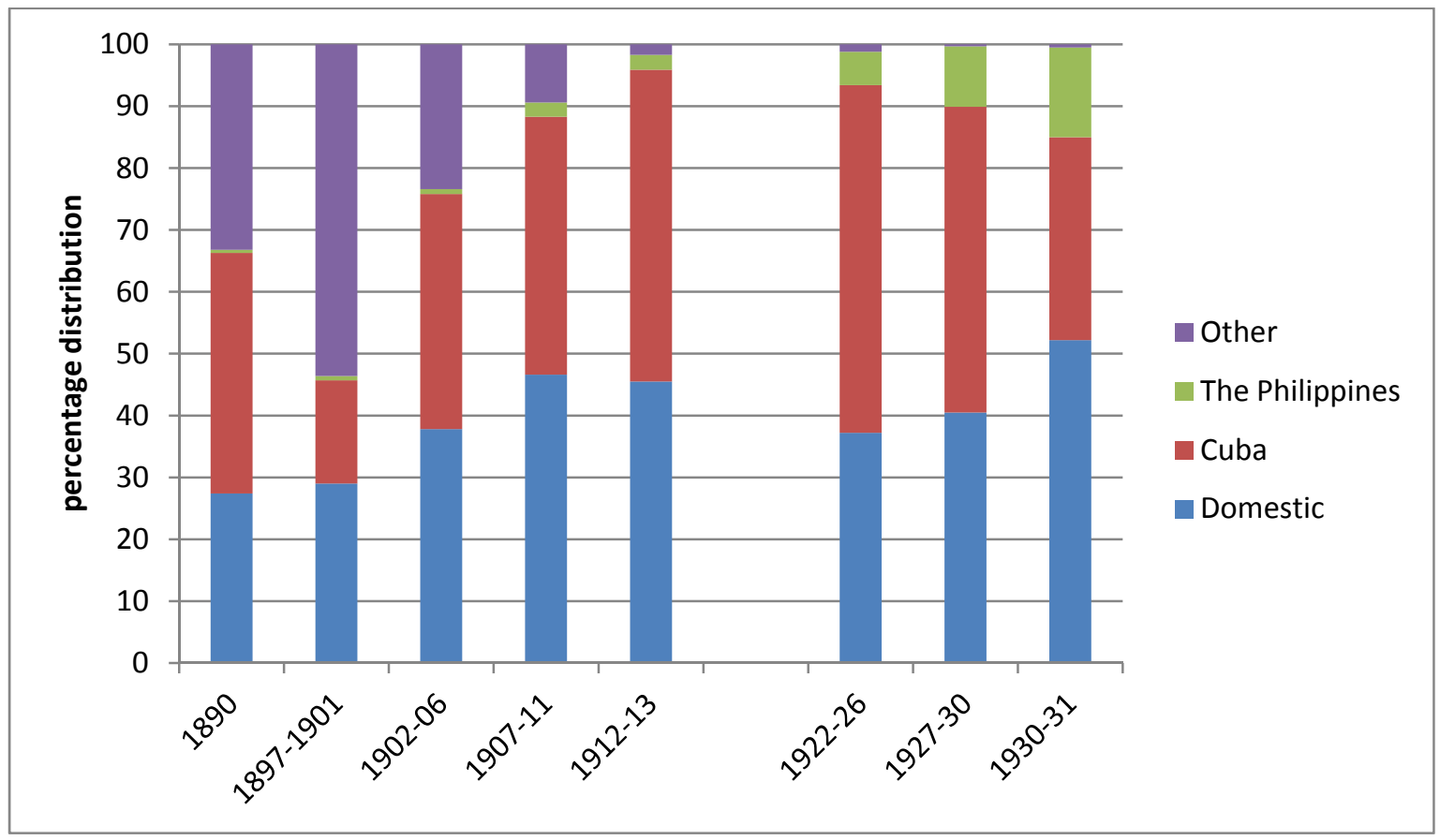

Source: Statistical Abstract of the United States, Foreign Commerce and Navigation of the United States, various issues

The sugar refining industry was concentrated but with a significant competitive fringe. In 1887, the American Sugar Refining Company (ASRC) was formed with the consolidation of 18 firms that controlled 80 percent of the industry's capacity (Genesove and Mullin 1998). The subsequent increase in the price of refined sugar led to the entry of new producers, the first of which began production in December 1889, sparking a two-year price war. This led the ASRC 
to buy out its competitors, a process that was complete by April 1892, at which point it controlled 95 percent of the nation's refining capacity. Subsequent entry eroded the ASRC's market share, but the entry of two large plants in late 1898 sparked another price war that lasted until June 1900, when some of the competitors consolidated their firms. However, by the early 1900s, the ASCR's market share had fallen to about 60 percent. In 1910, the federal government filed an antitrust suit against ASRC that was not resolved until a 1922 consent decree.

Genesove and Mullin (1998) find that the sugar refining industry was much more competitive than one might have believed given the ASCR's market share. Excluding the periods of price wars, they find that market conduct was equivalent to a symmetric 10 firm Cournot oligopoly. The ASRC kept prices of refined sugar low to deter the entry of new competitors and to prevent imports of refined sugar.

\section{U.S. Duties on Imported Sugar}

During the forty year period considered here (1890 to 1930), Congress enacted general tariff legislation eight times, often making large changes in the duties to sugar. ${ }^{5}$ This period is quite different from the post-World War II period when most U.S. tariff changes were negotiated in trade agreements with other countries and gradually phased in. In addition, exchange rate movements are not a feature of this period because the United States had a fixed exchange rate under the gold standard.

\footnotetext{
${ }^{5}$ These tariff changes are: the McKinley tariff of 1890, the Wilson-Gorman tariff of 1894, the Dingley tariff of 1897, the Payne-Aldrich tariff of 1909, the Underwood tariff of 1913, the Emergency Tariff Act of 1921, the Fordney-McCumber tariff of 1922, and the Smoot-Hawley tariff of 1930.
} 
Table 1 presents the U.S. import duty on raw sugar during this period. From 1883 to 1891, the duty was 2.25 cent per pound. ${ }^{6}$ The McKinley tariff of 1890 generally raised import duties, but placed sugar on the duty-free list in order to reduce government revenue, which at that time was excessive (Irwin 1997). Because the abolition of the sugar duty was going to be an enormous shock to the domestic sugar cane industry, the legislation stated that the sugar duty would take effect six months after the other duties, on April 1, 1891 instead of October 1, 1890.

In 1894, a 40 percent ad valorem duty on sugar was imposed, followed by a new specific duty in 1897. In 1903, the United States granted Cuba a 20 percent reduction in the duties applied to its products. This preference, granted in the aftermath of the Spanish-American war, ensured that virtually every pound of Cuban sugar was sent to the U.S. market. In 1909, Congress enacted a new tariff code but did not change the sugar duty. The sugar duty was scheduled to be abolished in the Underwood tariff of 1913 and a phase out began in March 1914, at which time the duty was cut to just over 1 cent per pound (Ellison and Mullin 1995). However, the provision to abolish the sugar duty was suspended when World War I broke out and the federal government needed revenue.

\footnotetext{
${ }^{6}$ Hawaii was given duty free access to the U.S. market in 1876, but imports from the island were relatively small and largely confined to the west coast.
} 
Table 1: U.S. Import Duties on Raw Sugar ( $96^{\circ}$ centrifugal)

\begin{tabular}{|l|l|l|}
\hline Year of Tariff Act & $\begin{array}{l}\text { Effective Date } \\
\text { (sugar only) }\end{array}$ & Rate of Duty \\
\hline 1883 & April 1, 1891 & 2.25 cents per pound \\
\hline 1890 & August 28, 1894 & Free \\
\hline 1894 & July 24, 1897 & 1.685 cents per pound \\
\hline 1897 & December 27, 1903 & 1.348 cents per pound \\
\hline $1903^{*}$ & August 6, 1909 & No change \\
\hline 1909 & March 1, 1914 & 1.0048 cents per pound \\
\hline 1913 & May 28, 1921 & 1.6 cents per pound \\
\hline 1921 & September 22, 1922 & 1.7648 cents per pound \\
\hline 1922 & June 18, 1930 & 2.00 cents per pound \\
\hline 1930 & & \\
\hline
\end{tabular}

* 20 percent tariff preference given only to sugar from Cuba.

After World War I, the sugar duty was increased in the Emergency Tariff of 1921 and in the Fordney-McCumber tariff of 1922, and then again in the Smoot-Hawley tariff of 1930. By this time, however, imports of sugar from the Philippines had been given duty free treatment. Therefore, these tariff increases raised the margin of preference given to Philippine sugar. The trade diversion that resulted could affect the price of Cuban sugar in a very different way than an across-the-board tariff increase. For this reason, the interwar tariff increases will be considered in a separate section.

The mixture of specific and ad valorem duties means that the price of imports is needed to calculate the height of the tariff. Figures 3 shows the ad valorem equivalent of the sugar 
duties from 1890 to 1914 using the import price of raw sugar described above. (The sample ends in July 1914 when sugar prices soar due to World War I). When the sugar duty was abolished in 1891, the equivalent ad valorem tariff was about 65 percent, making for a huge tariff reduction. The tariff was increased significantly in 1894 (from zero to 40 percent) and again in 1987 (from 40 to about 80 percent). By comparison, the tariff reductions in 1903 and 1914 were small in magnitude.

Figure 3: Tariff on Raw Sugar Imports, ad valorem equivalent, 1890-1914

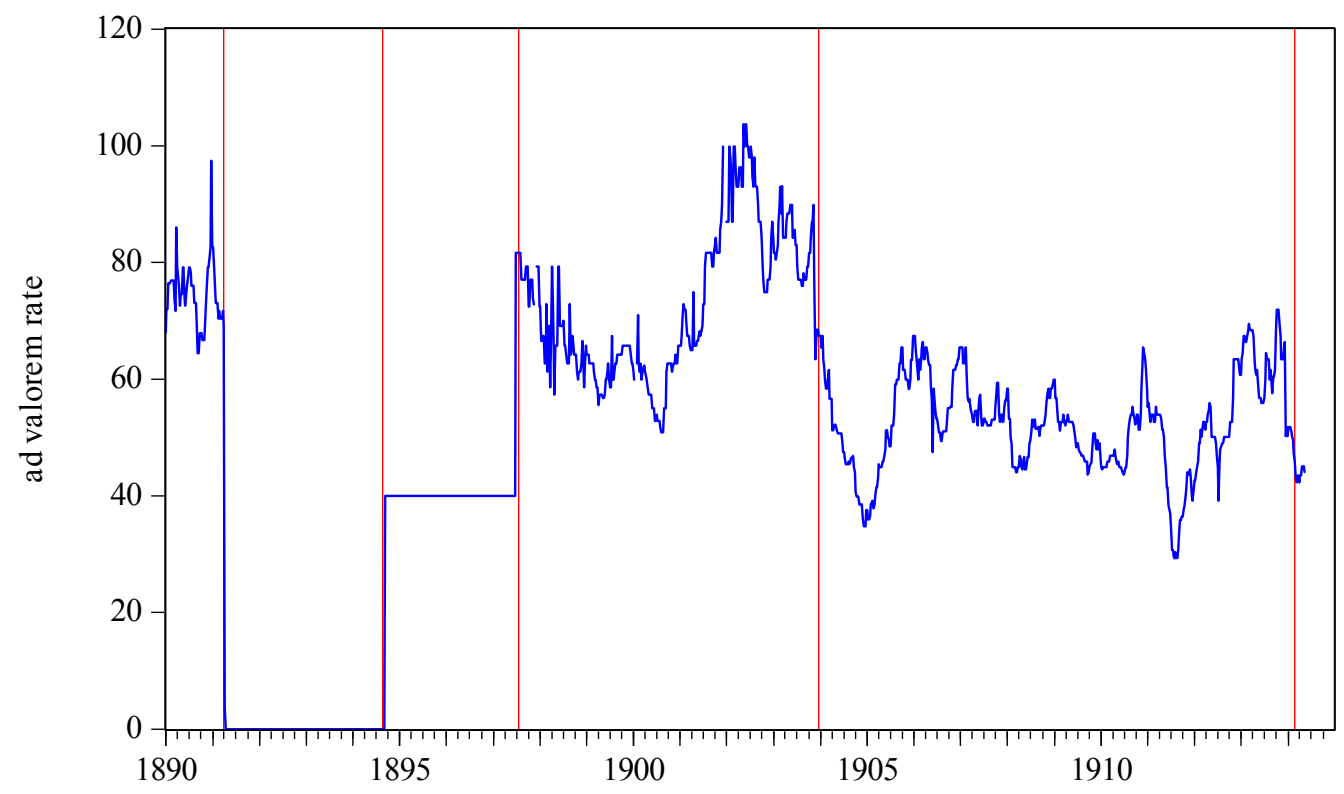

Note: Lines indicate changes in tariff rates.

Sugar Prices

Figure 4 shows weekly data on the landed price of raw Cuban sugar (cost and freight) and the domestic market price of raw sugar (inclusive of the duty) in New York City from 1890 to 1914. The impact of the three large initial tariff changes can be seen in these data. In 1891, when the sugar duty was eliminated, the domestic price of sugar immediately fell to the import price of sugar. This adjustment, as we will see, was instantaneous: the weekly observation is for 
April 2, the day after the tariff was removed, and on that day the domestic price was exactly equal to the previous landed price. One might have expected the import price of sugar to increase with the abolition of the tariff, but that is not apparent in the data. In 1894, by contrast, the domestic price appears to rise and the import price appears to fall in roughly equal magnitudes. The impact of the other tariff changes is more difficult to discern visually.

Figure 4: Raw Sugar Prices (96 ${ }^{\circ}$ centrifugal), New York City, weekly, 1890-1914

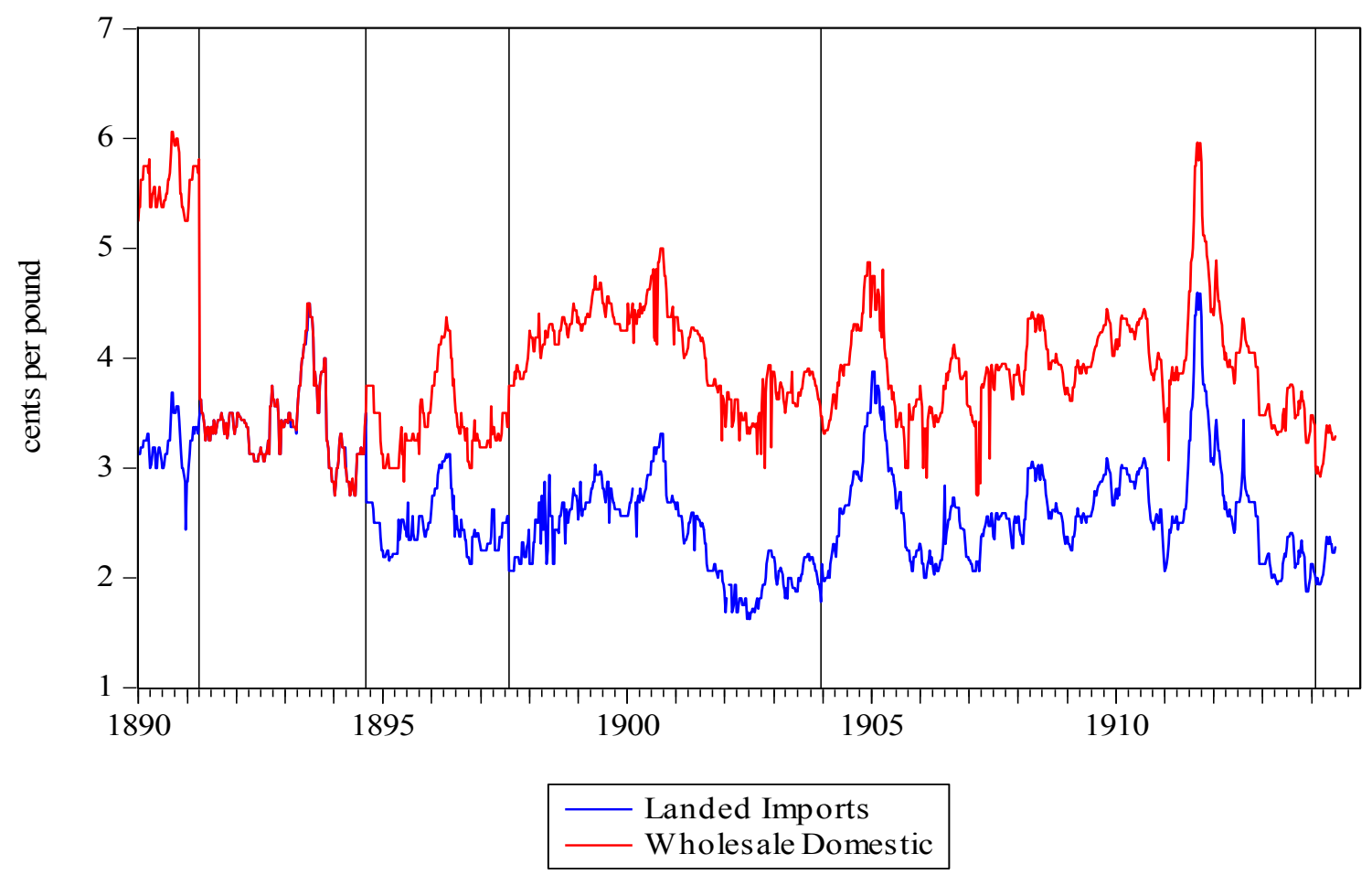

Source: collected from Willett and Gray's Weekly Statistical Sugar Trade Journal

The next section provides a more systematic exploration of the impact of the sugar duty on domestic and import prices. 


\section{Estimating Tariff Pass-Through: Specifications and Results}

Empirical studies of how sales taxes, exchange rates, and import tariffs pass-through to consumer prices all use fairly similar methods. Most studies use monthly data, which allow for other controls to be employed in the regression analysis, and a typical estimating equation is something akin to this:

(1) $\Delta \log \left(p_{D M}\right)_{t}=\alpha+\beta \Delta \log (1+\tau)_{t}+\mu \Delta \log \left(p_{W P I}\right)_{t}+\gamma \Delta \log (I P)_{t}+\varepsilon_{t}$

where $\mathrm{p}_{\mathrm{DM}}$ is the domestic price of an imported good at time $t, \tau$ is the (ad valorem) tariff, $\mathrm{p}_{\mathrm{WPI}}$ is the domestic wholesale price index at time t, and IP is industrial production (or some other control for economic activity) at time t. The regression also typically includes a dummy variable for the month, year, and other factors. The parameter of interest is $\beta$, which indicates the elasticity of the import price with respect to the import tariff and can be interpreted as the passthrough coefficient. To the extent that the tariff increases the domestic price of the imported good, we would expect that $\beta>0$. If the tariff is completely passed through to domestic prices, then $\beta=1$; if the tariff is completely absorbed by foreign exporters, then $\beta=0$. Unlike previous studies, we observe sugar prices on both sides of the tariff wall. Therefore, if import prices are used as the dependent variable, then $\beta$ can range from -1 to 0 .

During the periods in which the import duty took the form of a specific tariff, the ad valorem equivalent is constantly changing with movements in the price. It would be inappropriate to include these endogenous changes in the tariff as explanatory variables in the regression. Therefore, in the regressions that follow, the independent tariff variable only includes changes in the ad valorem tariff equivalent at the time the legislated tariff rate changes took effect, that is, the truly exogenous, legislated changes in the tariff. As previously noted, there are five such exogenous changes between 1890 and 1914, and three exogenous changes 
between 1920 and 1930 that will be considered in a subsequent section. The tariff variable is a quantitative dummy variable that equals $\Delta \log (1+\tau)=\log \left(1+\tau_{1}\right)-\log \left(1+\tau_{0}\right)$ for the week the new tariff takes effect. This means that the coefficient $\beta$ indicates the percentage passthrough to domestic or import prices, depending on which dependent variable is used.

Because tariff legislation takes time to move through Congress and must be signed by the president, all of the tariff changes were known in advance of their taking effect. Once tariff legislation was seriously considered by the House Ways and Means Committee, market participants knew if the sugar duty would be increased or decreased (depending on which party was in power), but the final duty might not be known until the report of the conference committee reconciled the inevitable differences between the House and Senate bill. The two chambers might take about a week to pass the reconciled bill and then send it to the president to sign; usually there was little uncertainty about whether it would be signed or not. These new duties would remain in effect at least through the next election, if not longer, as passing a tariff bill was an arduous political exercise that required unified government (the House, Senate, and presidency controlled by the same political party).

Because a tariff change was known in advance of its taking place, market participants could take advantage of this information and shift their purchases, potentially exaggerating changes in import prices. If the tariff was expected to increase at some date in the near future, purchasers could shift imports in advance of the rate increase, potentially driving up import prices in the weeks preceding its imposition and leading to a large decline in import prices after the tariff increase. If the tariff was expected to decrease at some date in the near future, purchasers might postpone importing until after the tax had been reduced, potentially reducing import prices prior to the change and then increasing import prices after the change. In this way, 
these anticipated tariff changes could exaggerate the immediate impact on the import price. In general, large inventory adjustments to these shifts in demand were not feasible because raw sugar deteriorates with time and hence firms did not hold large inventories that could be used to adjust to tariff changes. However, it is possible to control for the dynamic price effects simply by looking at the leads and lags of prices around the tariff shock.

One advantage in using weekly data is that we can identify price changes in a narrow window around the actual tariff change. One disadvantage in using weekly data is that other potential covariates are not collected at such a high frequency, limiting the number of controls that can be included in the regression. However, we can use less refined (so to speak) monthly data to compare the results with and without such controls.

\section{Baseline Results}

We first use equation 1 to examine the immediate impact of tariff changes with no price dynamics. Table 2 presents the baseline results of the impact of five tariff changes between 1890 and 1914 on the domestic (tariff inclusive) price and the landed import price in New York. Having both prices here gives us a check on the estimated incidence of both because the sum of the absolute value of the coefficients on import and domestic prices should be approximately one. Each coefficient by itself represents the percent of the tariff change absorbed by that price. The coefficient on the domestic price should always be positive (because a tariff increase would increase the domestic price, and vice versa), whereas the coefficient on the import price should always be negative (in the large country case) or zero (in the small country case).

As suggested by the data in Figure 3, the abolition of the tariff in 1891 was essentially completely passed through to domestic consumer prices with no discernible impact on the import price. The coefficient of 0.94 indicates that 94 percent of the tariff change was absorbed by the 
domestic price. The coefficient of -0.03 , which is not statistically significant, indicates that the landed price of imports was essentially unchanged. Both the 1894 and 1897 tariff increases appear to have reduced import prices, with 80 percent of the tariff change being absorbed by foreign exporters and only 20 percent of the tariff increase being passed through to domestic consumers. The small tariff change in 1903 had little apparent impact on domestic price and the tariff reduction of 1914 , like that in 1891 , appears to have been completely passed through to domestic prices.

Table 2: Tariff Incidence on Domestic and Import Prices

\begin{tabular}{lccc}
\hline $\begin{array}{l}\text { Year of Tariff } \\
\text { Change }\end{array}$ & $\begin{array}{c}\text { Percent change in } \\
\text { price due to tariff }\end{array}$ & $\begin{array}{c}\text { Domestic Price } \\
\text { (NYC) }\end{array}$ & $\begin{array}{c}\text { Import Price } \\
\text { (NYC) }\end{array}$ \\
\hline \multirow{2}{*}{1891} & -50 & $0.94^{* *}$ & -0.03 \\
& & $(0.07)$ & $(0.08)$ \\
1894 & +34 & $0.19^{*}$ & $-0.80^{* *}$ \\
& & $(0.11)$ & $(0.11)$ \\
1897 & +26 & $0.39^{* *}$ & $-0.86^{* *}$ \\
& & $(0.14)$ & $(0.15)$ \\
1903 & -17 & 0.13 & 0.27 \\
& & $(0.21)$ & $(0.23)$ \\
& -10 & $1.20^{* *}$ & 0.20 \\
& & $(0.36)$ & $(0.38)$ \\
\hline
\end{tabular}

Note: Weekly data from January 1, 1890-July 31, 1914. Number of observations is 1,278. Month and year fixed effects included. Standard errors in parenthesis. 
As mentioned earlier, there may be some important price dynamics associated with tariff changes because the changes are anticipated. In the case of a tariff increase, domestic consumers may shift their purchases forward in advance of the tariff change, driving up prices before the tariff takes effect and driving down prices after it takes effect. In the case of a tariff decrease, domestic consumers will shift their purchases back until after the tariff change takes effect, driving down prices before the tariff takes effect and driving up prices after it takes effect. These dynamics may exaggerate the price changes seen in a narrow one-week window around the time that the tariff takes effect.

To see if there are any such price dynamics around the time of a tariff change, Tables 3 includes two leads and two lags in the regressions using the weekly data. With the exception of one case, it appears that tariff pass-through is nearly instantaneous and contemporaneous with the change in the tariff rate. In the case of the tariff reductions in 1891 and 1914, there is no change in the interpretation from the previous results: the tariff change is completely passed through to domestic prices with no impact on the import price. (The reduction in the import price in week $\mathrm{t}+1$ in 1903 may be noise because the tariff reduction would be expected to increase the import price, if anything.)

However, the dynamics change the story for the 1894 tariff increase: there was a run-up in the import price in the week prior to the tariff increase. When that is taken into account, the impact of the tariff on the import price falls from 80 percent to 60 percent. One can also see the impact on domestic prices, which increased by 20 percent of the tariff change two weeks prior to the tariff taking effect and another 20 percent on the week the tariff took effect, suggesting that 40 percent of the tariff was passed through to consumer prices. Yet, it still appears that most of the tariff increase in 1897 was absorbed by a reduction in the import price, although domestic 
prices increased by nearly 40 percent of the tariff increase. In this case, the sum of the coefficients do not approximately equal one, leaving us with some uncertainty about whether the pass through was 40 percent on the domestic price and 60 percent on import prices, or more like 20 percent domestic and 80 percent import.

Table 3: Dynamic Adjustment of Prices in Response to Tariff Shock Import Price

\begin{tabular}{|c|c|c|c|c|c|}
\hline & $t-2$ & $t-1$ & $t$ & $t+1$ & $t+2$ \\
\hline 1891 & $\begin{array}{c}0.05 \\
(0.08)\end{array}$ & $\begin{array}{c}-0.06 \\
(0.08)\end{array}$ & $\begin{array}{c}-0.03 \\
(0.08)\end{array}$ & $\begin{array}{c}-0.07 \\
(0.08)\end{array}$ & $\begin{array}{c}0.07 \\
(0.08)\end{array}$ \\
\hline 1894 & $\begin{array}{c}0.10 \\
(0.12)\end{array}$ & $\begin{array}{l}0.21^{*} \\
(0.12)\end{array}$ & $\begin{array}{l}-0.79 * \\
(0.12)\end{array}$ & $\begin{array}{c}-0.00 \\
(0.12)\end{array}$ & $\begin{array}{c}-0.00 \\
(0.12)\end{array}$ \\
\hline 1897 & $\begin{array}{c}0.06 \\
(0.15)\end{array}$ & $\begin{array}{l}-0.03 \\
(0.15)\end{array}$ & $\begin{array}{l}-0.87^{*} \\
(0.15)\end{array}$ & $\begin{array}{c}-0.04 \\
(0.15)\end{array}$ & $\begin{array}{c}-0.04 \\
(0.15)\end{array}$ \\
\hline 1903 & $\begin{array}{c}0.05 \\
(0.23)\end{array}$ & $\begin{array}{c}0.15 \\
(0.15)\end{array}$ & $\begin{array}{c}0.25 \\
(0.23)\end{array}$ & $\begin{array}{l}-1.06^{*} \\
(0.23)\end{array}$ & $\begin{array}{c}0.41 \\
(0.23)\end{array}$ \\
\hline 1914 & $\begin{array}{c}0.41 \\
(0.38)\end{array}$ & $\begin{array}{c}0.25 \\
(0.38)\end{array}$ & $\begin{array}{c}0.22 \\
(0.38)\end{array}$ & $\begin{array}{c}0.37 \\
(0.38)\end{array}$ & $\begin{array}{c}-0.22 \\
(0.38)\end{array}$ \\
\hline \multicolumn{6}{|c|}{ Domestic Price } \\
\hline & $t-2$ & $t-1$ & $t$ & $t+1$ & $t+2$ \\
\hline 1891 & $\begin{array}{c}0.03 \\
(0.07)\end{array}$ & $\begin{array}{c}-0.04 \\
(0.07)\end{array}$ & $\begin{array}{c}0.94^{*} \\
(0.07)\end{array}$ & $\begin{array}{c}0.00 \\
(0.07)\end{array}$ & $\begin{array}{c}0.07 \\
(0.07)\end{array}$ \\
\hline 1894 & $\begin{array}{l}0.22 * \\
(0.11)\end{array}$ & $\begin{array}{c}0.10 \\
(0.11)\end{array}$ & $\begin{array}{l}0.20^{*} \\
(0.11)\end{array}$ & $\begin{array}{c}0.00 \\
(0.11)\end{array}$ & $\begin{array}{c}0.00 \\
(0.11)\end{array}$ \\
\hline 1897 & $\begin{array}{l}-0.15 \\
(0.14)\end{array}$ & $\begin{array}{l}-0.02 \\
(0.14)\end{array}$ & $\begin{array}{l}0.38^{*} \\
(0.14)\end{array}$ & $\begin{array}{c}-0.03 \\
(0.14)\end{array}$ & $\begin{array}{c}-0.03 \\
(0.14)\end{array}$ \\
\hline 1903 & $\begin{array}{c}-0.02 \\
(0.21)\end{array}$ & $\begin{array}{l}0.78^{*} \\
(0.21)\end{array}$ & $\begin{array}{c}0.13 \\
(0.21)\end{array}$ & $\begin{array}{c}-0.02 \\
(0.21)\end{array}$ & $\begin{array}{c}0.23 \\
(0.21)\end{array}$ \\
\hline 1914 & $\begin{array}{c}0.21 \\
(0.36)\end{array}$ & $\begin{array}{c}0.13 \\
(0.36)\end{array}$ & $\begin{array}{l}1.21^{*} \\
(0.36)\end{array}$ & $\begin{array}{c}0.25 \\
(0.36)\end{array}$ & $\begin{array}{c}-0.14 \\
(0.36)\end{array}$ \\
\hline
\end{tabular}

Note: Weekly data from January 1890 - June 1914. Number of observations is 1,275. Standard errors in parenthesis. 
Because of the high frequency nature of the data, we can also present time series plots of the import (landed) price and the domestic (post-customs) price of sugar in New York City on a weekly basis. Figure 5 shows plots for the 1891 decrease, the 1984 and 1897 increases, and the 1914 decrease, when daily data are also available. The plots simply confirm the regression analysis: that the two tariff reductions are almost entirely passed through to consumer prices, while the three tariff increases are split between higher domestic prices and lower import prices.

\section{Figure 5: Weekly Sugar Prices in New York City}

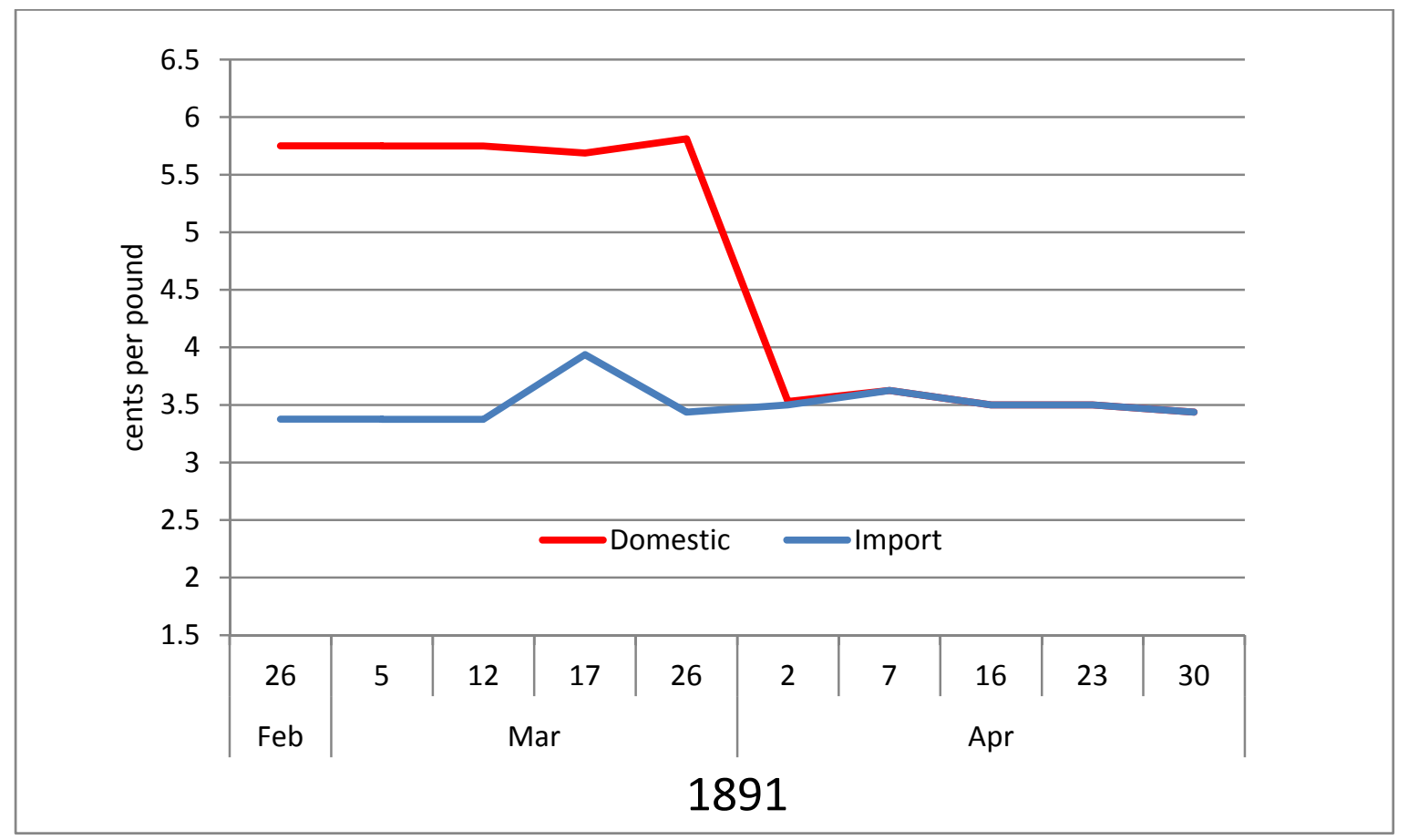



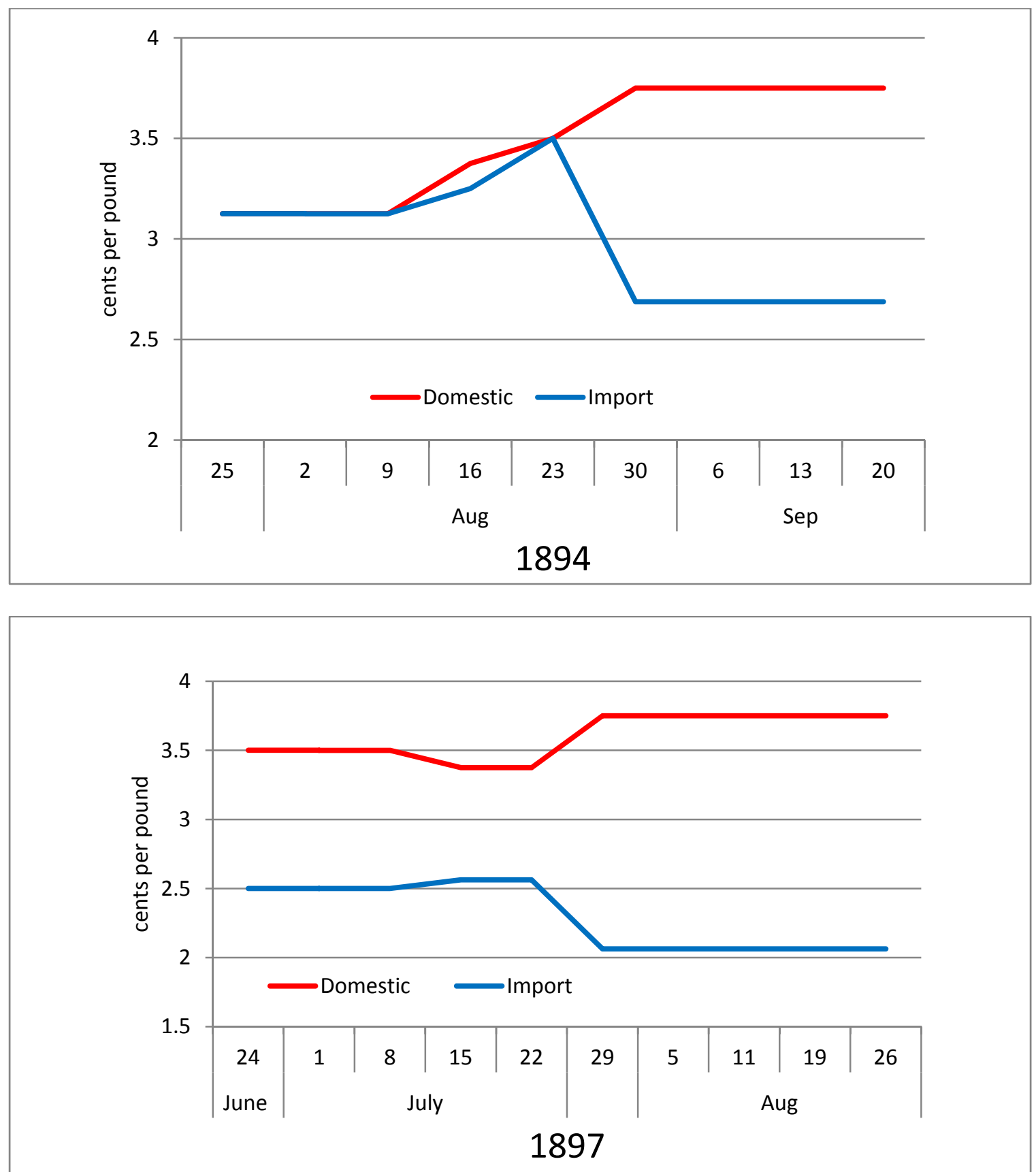


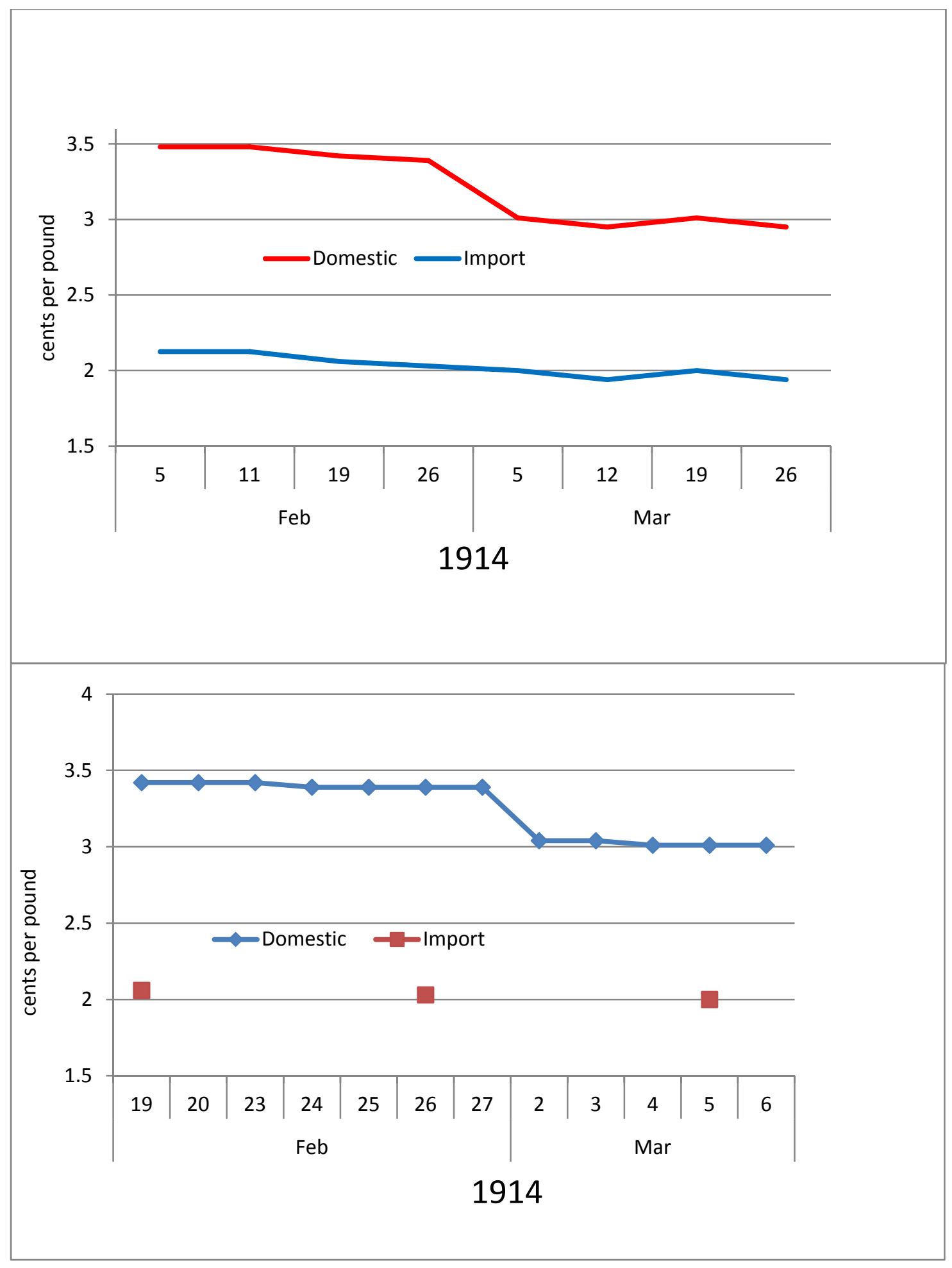




\section{Explaining the Asymmetry}

What explains the asymmetry in which tariff reductions have little impact on import prices while tariff increases reduce import prices? ${ }^{7}$ The most straightforward explanation is that the response of demand to tariff increases and decreases is not symmetric. The key is not just that tariff changes are anticipated, but also that they are expected to be (relatively) permanent. When the tariff is known to increase at some specific date in the near future, there is a powerful incentive to import foreign goods prior to the date at which the tariff takes effect. When the tariff is known to decrease at some specific date in the near future, there is an incentive to postpone or delay importing until after the tariff is reduced, but there is no strong incentive to import large quantities immediately after the lower tariff takes effect. Because the lower tariffs will be in effect for many months or years after a tariff bill is passed, there is no urgency to import more within a specific time frame.

Figure 6 demonstrates this asymmetry by presenting the year-over-year percentage change in monthly import volume for three months before and after a tariff change. In the case of the three tariff reductions (1891, 1903, and 1914), the lines are fairly flat. There is some evidence of a slowdown in imports in the month prior to the tariff reduction, particularly in 1914, but no major surge in imports after the lower tariff takes effect.

The pattern is quite different for the two tariff increases $(1894,1897)$. The response to the 1894 tariff increase, which took the sugar duty from zero to 40 percent, is most dramatic. Import surged more than 200 percent (from a year earlier) two months prior to the higher tariff taking effect, and then collapsed, falling by a large amount and remaining depressed for several months after the tariff took effect. While there was no run-up in imports prior to the imposition

\footnotetext{
${ }^{7}$ Asymmetric price adjustment to cost or tax shocks have been found in many other cases, such as gasoline (Borenstein, Cameron, and Gilbert 1997).
} 
of the 1897 tariff increase, imports also remained significantly depressed for 3-4 months after it took effect.

In the case of 1894 , why does the impact occur two months prior to the tariff increase and not the month before? A plausible explanation is that once the Senate seems close to passing the bill, the chance of the new tariff taking effect goes up significantly, although there will be tremendous uncertainty about the exacting timing of when it will be imposed. Therefore, giving the ordering and shipping lags between Cuba and New York, merchants did not want to risk paying a higher duty on a large imported cargo.

\section{Figure 6: Percentage Change (year-over-year) in Monthly Imports around Tariff Change}

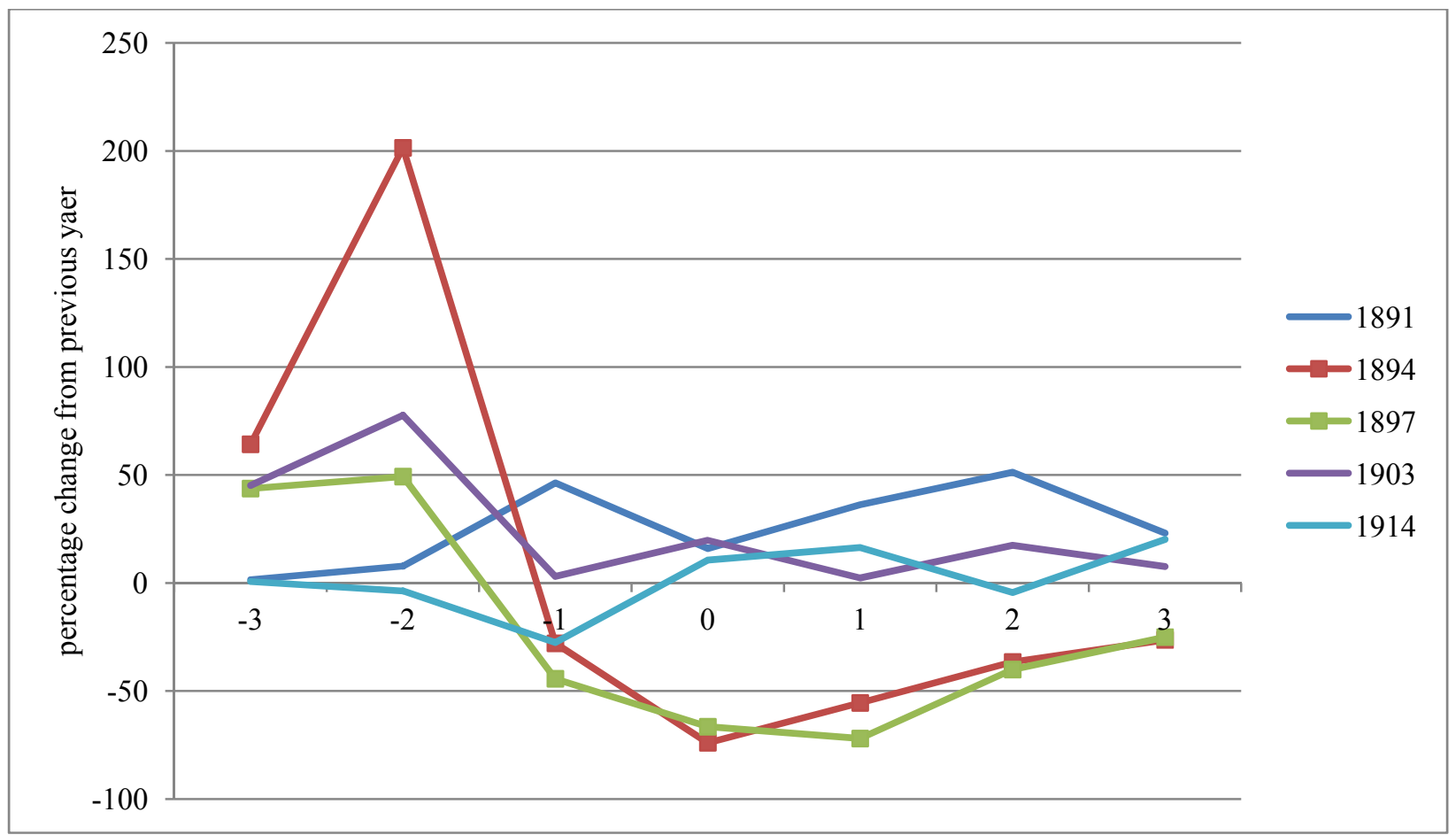

Note: tariff increases in 1894 and 1897 (marked by squares); tariff decreases in other years. Source: Willett and Gray's Weekly Statistical Sugar Trade Journal 
Thus, the import price of sugar does not increase after a tariff reduction because there is no surge in demand, and therefore no immediate pressure put on existing supply, after the tariff change. Conversely, the import price of sugar falls significantly after a tariff increase because refiner demand falls sharply in the immediate aftermath of the tariff change.

Supply side factors might also account for the lack of any price increase after a U.S. tariff reduction (Marion and Muehlegger 2011). In particular, if the Cuban sugar industry was characterized by excess capacity, then additional output could accommodate any increase in U.S. demand with a tariff reduction with no increase in costs. Furthermore, shipments to Europe and other markets could be diverted to the U.S. market if there was an increase in demand. With a fall in demand, Cuban producers might be forced to take a reduction in price if they continue producing at previous levels in order to pay off the fixed costs of running the sugar mill or plantation.

\section{Extensions}

This section considers two extensions of the previous analysis: (1) a robustness check using a different set of monthly prices, which allows for control of other influences on price, and (2) a look at the pass-through of raw sugar prices to granulated (refined) sugar prices.

\section{Monthly Prices}

One problem with using weekly data is that it is difficult to control for other factors that may be influencing price movements. The advantage of using monthly prices is that controls can be included for other covariates, such as wholesale prices and industrial production, in the regression analysis. The disadvantage of using monthly prices is that commodity prices (such as sugar) are much more volatile than finished goods prices and the monthly data can mask high 
frequency (intra-month) price movements that might help make more precise any inference about the impact of specific tax changes.

These monthly data provide a check on the weekly results since they rely on a different source for the sugar prices. However, monthly data only exist for the import price, not the domestic (post-customs) price, of sugar. The standard import price series is a unit value (value of imports divided by the quantity of imports) and, in the case of sugar, is calculated and reported in the Monthly Summary of the Foreign Commerce of the United States. The unit value is based on aggregate U.S. imports in a given month; it is not specific to New York City or imports from Cuba.

Table 4 reports the results of estimating equation (1) with a monthly lead and lag in the price as well. Results are shown with and without controls for industrial production and wholesale prices. ${ }^{8}$ In the case of the three tariff reductions $(1891,1903,1914)$, there is no discernible change in the monthly import price, consistent with the findings reported above that the tariff reduction was passed through to purchasers of raw sugar. In the case of the 1894 tariff increase, the import price does fall in the month the tariff is imposed, but is also increases about to its previous level in the next month. In 1897, the behavior of prices is different: average prices increase in advance of the tariff change and then fall after the tariff was imposed.

While these results are consistent with the previous findings about a tariff decrease, they are less clear about the impact of the two tariff increases. The problems with using monthly data are that the precision of weekly data is lost, and that the unit value may reflect shifts in the composition of imports across non-homogenous commodities (i.e., different qualities of sugar).

\footnotetext{
${ }^{8}$ In the regressions reported below, the wholesale price index is from the Bureau of Labor Statistics and industrial production is from Miron and Romer (1990). The BLS index can be found in the NBER Macro-history database (http://www.nber.org/databases/macrohistory/data/04/m04048c.db).
} 
Table 4: Tariff Pass-Through using Monthly Import Price Data

Dependent variable: Change in log of the average import price of raw sugar

\begin{tabular}{|c|c|c|c|c|}
\hline & $\mathrm{t}-1$ & $\mathrm{t}$ & $\mathrm{t}+1$ & $\begin{array}{l}\text { Controls for } \\
\text { WPI and IP }\end{array}$ \\
\hline \multirow[t]{2}{*}{1891} & $\begin{array}{c}-0.62 \\
(0.79)\end{array}$ & $\begin{array}{c}-0.03 \\
(0.79)\end{array}$ & $\begin{array}{c}0.13 \\
(0.79)\end{array}$ & No \\
\hline & $\begin{array}{l}-0.56 \\
(0.79)\end{array}$ & $\begin{array}{l}-0.09 \\
(0.79)\end{array}$ & $\begin{array}{c}0.10 \\
(0.79)\end{array}$ & Yes \\
\hline \multirow[t]{2}{*}{1894} & $\begin{array}{c}0.17 \\
(0.15)\end{array}$ & $\begin{array}{l}-0.30^{*} \\
(0.05)\end{array}$ & $\begin{array}{c}0.47^{*} \\
(0.08)\end{array}$ & No \\
\hline & $\begin{array}{c}0.19 \\
(0.16)\end{array}$ & $\begin{array}{l}-0.29^{*} \\
(0.16)\end{array}$ & $\begin{array}{c}0.47^{*} \\
(0.16)\end{array}$ & Yes \\
\hline \multirow[t]{2}{*}{1897} & $\begin{array}{l}0.71 * \\
(0.31)\end{array}$ & $\begin{array}{l}0.81 * \\
(0.31)\end{array}$ & $\begin{array}{c}-0.54^{*} \\
(0.31)\end{array}$ & No \\
\hline & $\begin{array}{c}0.71 * \\
(0.31)\end{array}$ & $\begin{array}{l}0.78^{*} \\
(0.31)\end{array}$ & $\begin{array}{c}-0.57^{*} \\
(0.31)\end{array}$ & Yes \\
\hline \multirow[t]{2}{*}{1903} & $\begin{array}{l}-0.02 \\
(0.08)\end{array}$ & $\begin{array}{c}-0.03 \\
(0.08)\end{array}$ & $\begin{array}{c}0.01 \\
(0.08)\end{array}$ & No \\
\hline & $\begin{array}{l}-0.02 \\
(0.08)\end{array}$ & $\begin{array}{l}-0.02 \\
(0.08)\end{array}$ & $\begin{array}{c}0.01 \\
(0.08)\end{array}$ & Yes \\
\hline \multirow[t]{2}{*}{1914} & $\begin{array}{c}0.11 \\
(0.08)\end{array}$ & $\begin{array}{c}0.04 \\
(0.08)\end{array}$ & $\begin{array}{l}-0.05 \\
(0.08)\end{array}$ & No \\
\hline & $\begin{array}{c}0.11 \\
(0.08)\end{array}$ & $\begin{array}{c}0.05 \\
(0.08) \\
\end{array}$ & $\begin{array}{l}-0.04 \\
(0.08) \\
\end{array}$ & Yes \\
\hline
\end{tabular}

Note: Monthly data, January 1890-July 1914, 293 observations. Month and year fixed effects included.

Figure 7 presents a visualization of these results by showing import prices three months before and after each of the tariff changes, with the prices being normalized to 100 on the month the tariff change takes effect. Around the time of the three tariff reductions, import prices are 
fairly stable, but they fall significantly - around 25 percent - after the two tariff increases in 1894 and 1897. (The 25 percent reduction in 1894 is roughly consistent with the 80 percent absorption of the 34 percentage point change in tariffs in table 2,) However, the pattern is different in these two cases: in the case of the 1894 increase, prices are stable and then fall significantly (and remain low), whereas in the case of the 1897 increase, import prices rise significantly two months prior to the tariff taking effect and then fall back to their previous level. Thus, the only clear cut evidence of a higher tariff reducing the price of imports is in 1894; recall as well that the pattern of the quantity of sugar imports is consistent with a larger price impact in 1894.

\section{Figure 7: Monthly Import Prices around Tariff Changes}

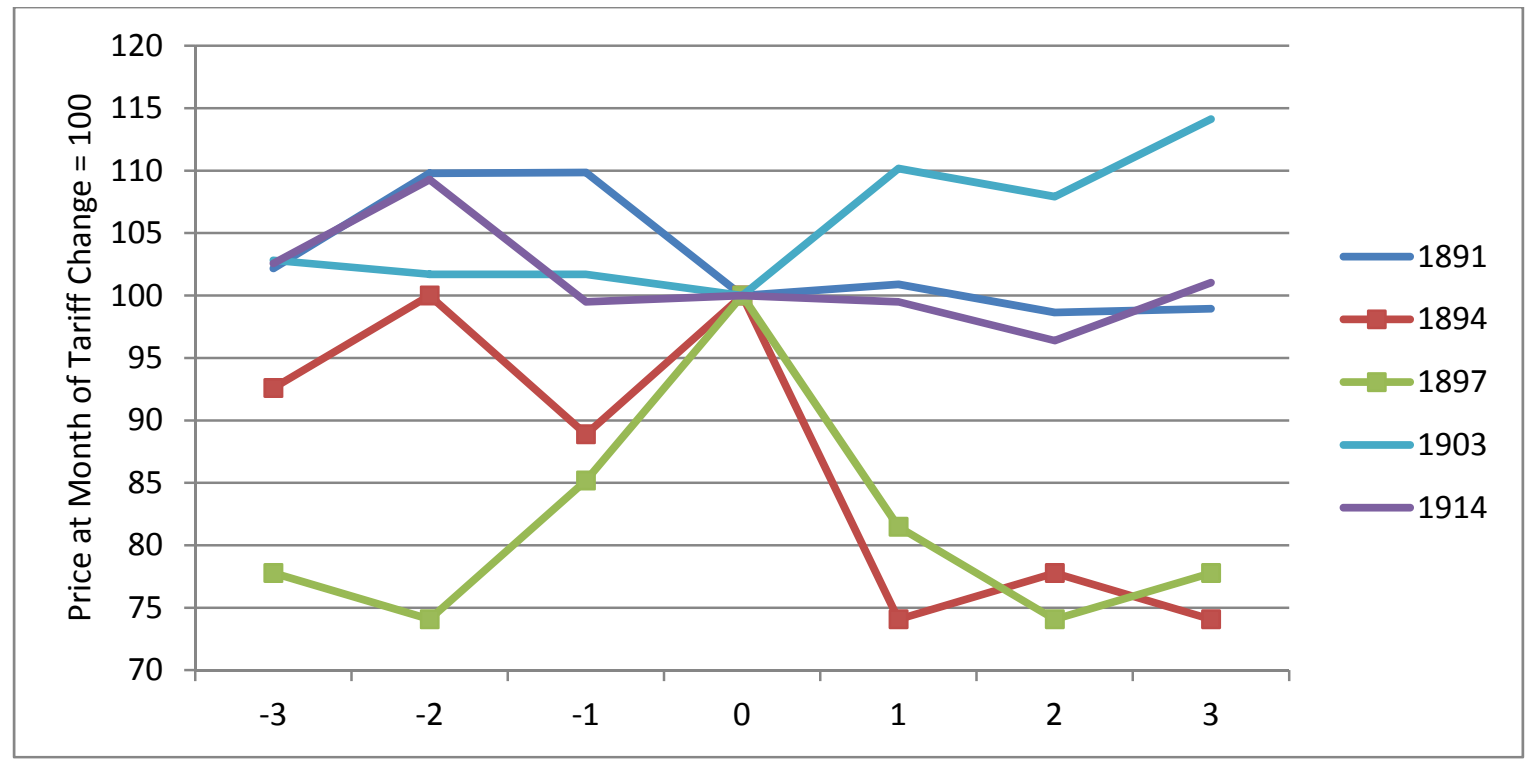

Note: tariff increases in 1894 and 1897 (marked by squares); tariff decreases in other years.

\section{Pass-through to Final Goods Prices: Granulated Sugar}

Another pass-through relationship is that between the price of raw sugar and the price of granulated sugar. This involves the share of raw sugar in the cost of production of refined 
(granulated) sugar and the market structure/degree of competition in the sugar market. Willett and Gray's Weekly Statistical Sugar Trade Journal also reports weekly prices of granulated (refined) sugar in New York City. The price of granulated sugar is much more of an "administered" price with infrequent changes, whereas the price of raw sugar changes almost every week. According to the Census of Manufactures for 1909, the cost of materials comprised 90 percent of the value of products in the sugar refining industry; therefore, any significant change in those costs (almost entirely sugar) should have an impact on the prices of refined sugar goods.

However, Table 5 reports that only the 1891 tariff reduction was immediately passed through to the wholesale price of granulated sugar. This was a period in which there was a "price war" between the American Sugar Refining Company and new entrants (Genesove and Mullin 1998). In other instances, tariff changes had no discernable impact on the price of granulated sugar in a two week window of the event. However, this window may be too narrow to determine the true extent of pass-through because the frequency of adjustment of granulated sugar prices was so much lower than with raw sugar prices. 
Table 5: Pass Through to Wholesale Price of Granulated Sugar, New York

Domestic Price - New York City

\begin{tabular}{lccccc}
\hline & $t+2$ & $t+1$ & $t$ & $t-1$ & $t-2$ \\
\hline 1891 & 0.08 & 0.03 & $0.62^{*}$ & 0.00 & 0.00 \\
& $(0.04)$ & $(0.04)$ & $(0.04)$ & $(0.04)$ & $(0.04)$ \\
1894 & & & & \\
& -0.00 & 0.08 & 0.07 & 0.01 & $-0.13^{*}$ \\
& $(0.06)$ & $(0.06)$ & $(0.06)$ & $(0.06)$ & $(0.06)$ \\
1897 & & & & -0.03 \\
& -0.02 & 0.04 & 0.03 & -0.03 & $(0.07)$ \\
1903 & $(0.07)$ & $(0.07)$ & $(0.07)$ & $(0.07)$ & 0.01 \\
& & & & -0.10 & $(0.11)$ \\
1914 & -0.02 & 0.02 & 0.06 & $(0.11)$ & 0.19 \\
& $(0.11)$ & $(0.11)$ & $(0.11)$ & 0.31 & $(0.18)$ \\
\hline
\end{tabular}

Note: The number of observations is 1,275 using weekly data from January 1890 to June 1914 . Standard errors in parenthesis.

\section{Interwar Tariff Changes}

The tariff changes in the interwar period have a slightly different character than preWorld War I tariff changes since another major foreign supplier, the Philippines, was given duty free treatment. Although Philippine sugar received this treatment in 1909, the Philippines did not emerge as a major sugar exporter to the United States until after the war. This change makes the tariff increases in 1921, 1922, and 1930 more like an increase in the margin of preference given to Philippine sugar than a uniform, across-the-board tariff increase as was the case prior to World War I. As Chang and Winters (2002) note in the context of preferential trade agreements, increasing the tariff on Cuban (and other imported) sugar would lead to trade diversion and a 
terms-of-trade gain for the preferred country (the Philippines) and a terms-of-trade loss for the excluded country (Cuba).

Figure 6 shows the weekly ad valorem tariff on imported sugar (using the delivered price in New York). The tariff increase in 1921 is pronounced, but the smaller increase in 1922 is more difficult to detect. Because of the interaction between the deflation after 1929 and the specific duty, the ad valorem tariff rose from about 80 percent to nearly 200 percent by mid1930.

Figure 6: Tariff on Raw Sugar Imports, ad valorem equivalent, 1921-1930

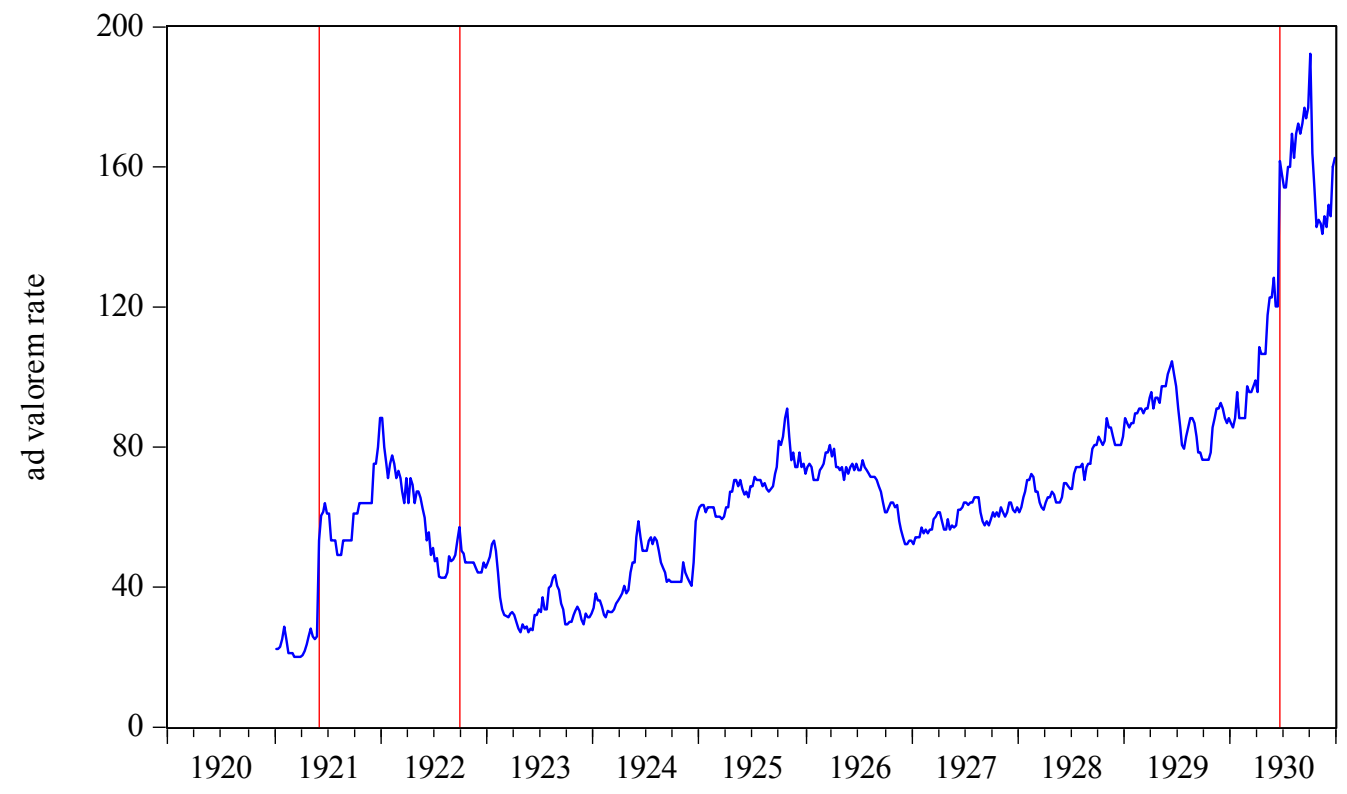

Figure 7 shows the landed and the customs-cleared prices of Cuban sugar in New York City over the same period. Unlike the pre-war period, it is difficult to see the impact of the tariff changes on sugar prices. In 1921, sugar prices were falling rapidly during a period of deflation, but they started to rise in 1922. Given the scale of the price changes, the tariff changes amounting to just a fraction of a cent in some cases - are very difficult to detect. 
Figure 7: Raw Sugar Prices (96 centrifugal), Cuba and New York, weekly, 1921-1930

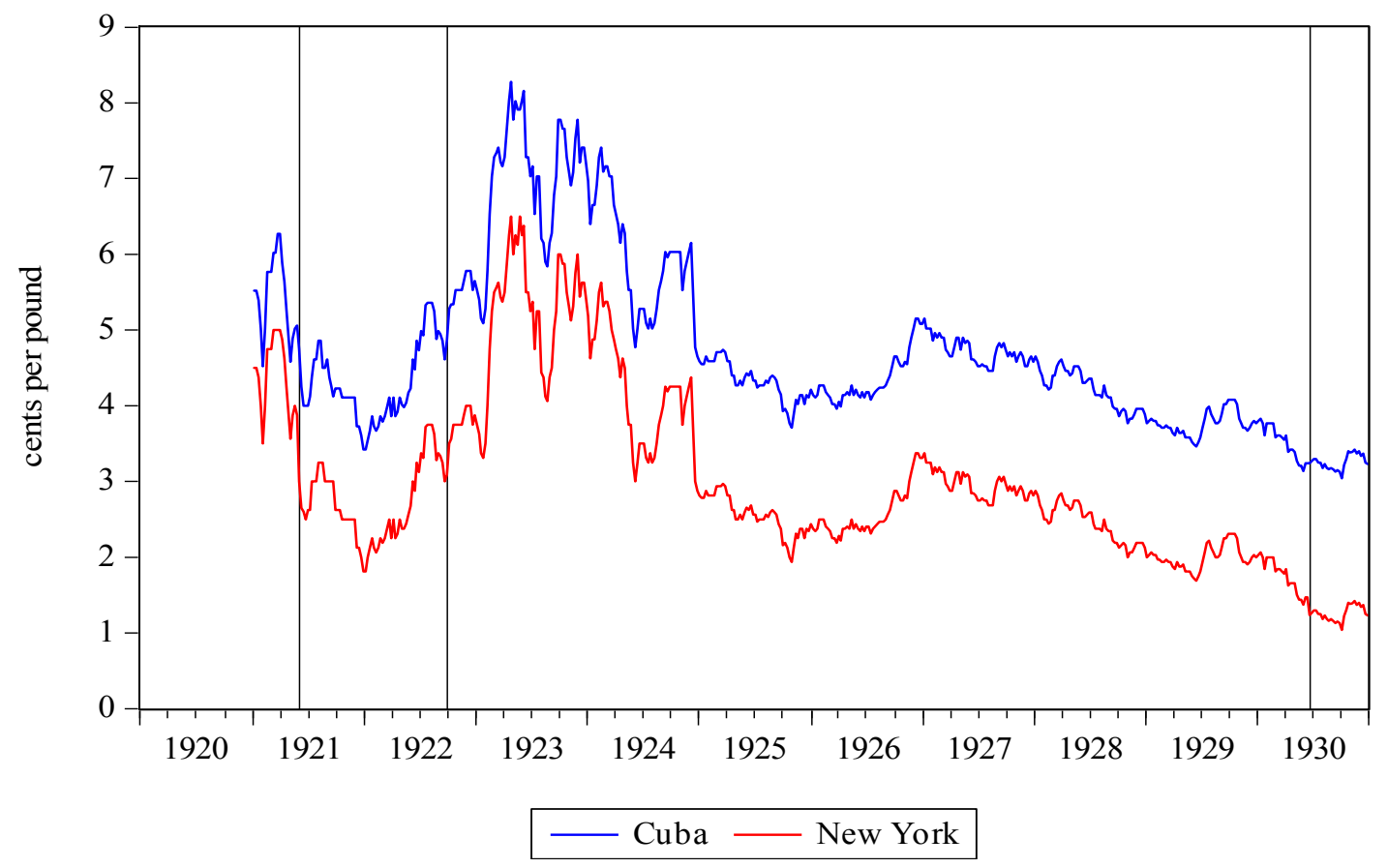

Table 6 presents the regression results for the three tariff increases of the interwar period. In two of the three cases (1921 and 1930), the import price from Cuba seems to bear the entire burden of the tariff. However, the smaller tariff increase in 1922 seems to have been passed on to consumers and is reflected in the New York price (although the coefficient is not statistically significant). Interestingly, this is one of the few periods when the Cuban sugar industry was operating at full capacity (Dye 2012). Regressions allowing for dynamic price adjustments (results not reported) do not change these interpretations. 
Table 6: Tariff Incidence on Domestic and Import Prices

\begin{tabular}{|c|c|c|c|}
\hline $\begin{array}{l}\text { Year of } \\
\text { Tariff }\end{array}$ & $\begin{array}{l}\text { Percent change in } \\
\text { price due to tariff }\end{array}$ & $\begin{array}{c}\text { Domestic Price } \\
\text { (New York) }\end{array}$ & $\begin{array}{l}\text { Import Price } \\
\text { (Cuba) }\end{array}$ \\
\hline 1921 & +12 & $\begin{array}{l}-0.43 \\
(0.27)\end{array}$ & $\begin{array}{l}-1.99 * \\
(0.41)\end{array}$ \\
\hline 1922 & +4 & $\begin{array}{c}0.96 \\
(0.81)\end{array}$ & $\begin{array}{c}0.14 \\
(1.23)\end{array}$ \\
\hline 1930 & +16 & $\begin{array}{c}0.04 \\
(0.20)\end{array}$ & $\begin{array}{l}-1.02 * \\
(0.31)\end{array}$ \\
\hline
\end{tabular}

Note: Weekly data from January 1, 1921-December 31, 1930. Number of observations is 520. Month and year fixed effects included.

During this period, however, daily data on domestic sugar prices in New York City can be combined with the weekly data on the landed price of sugar to get a better picture of tariff incidence. Figure 8 largely supports the conclusions of the regressions. In 1921, the price of imported sugar was falling rapidly; while the domestic price does increase slightly the day after the new tariff takes effect, it quickly falls with the landed import price. In 1922, the domestic price increases the full extent of the new duty on Monday, September 25. By contrast, the domestic price of sugar is unchanged in 1930 while the import price falls by the 0.24 cent tariff increase. 
Figure 8: Daily and Weekly Sugar Price Data, 1921, 1922, 1930
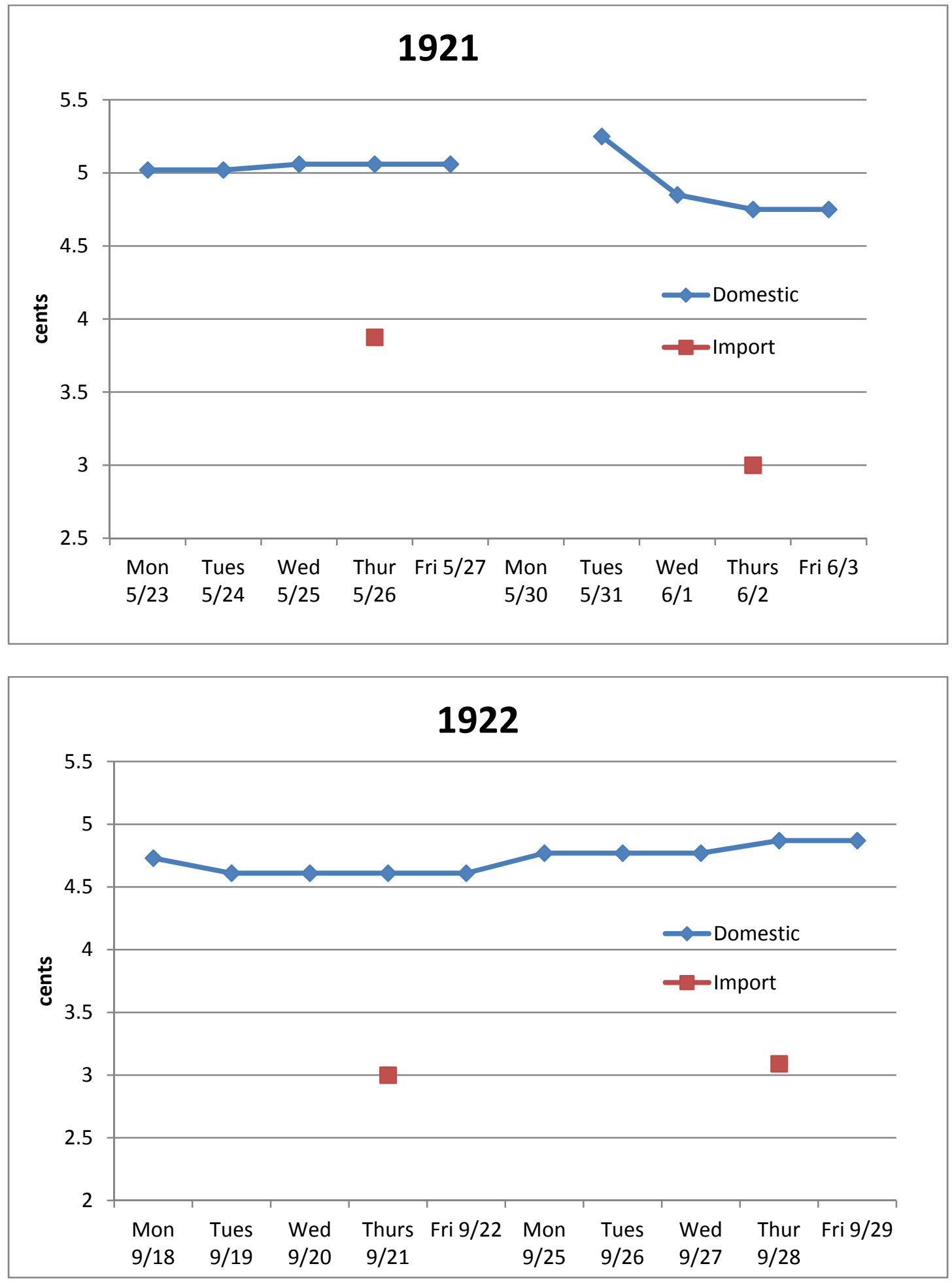


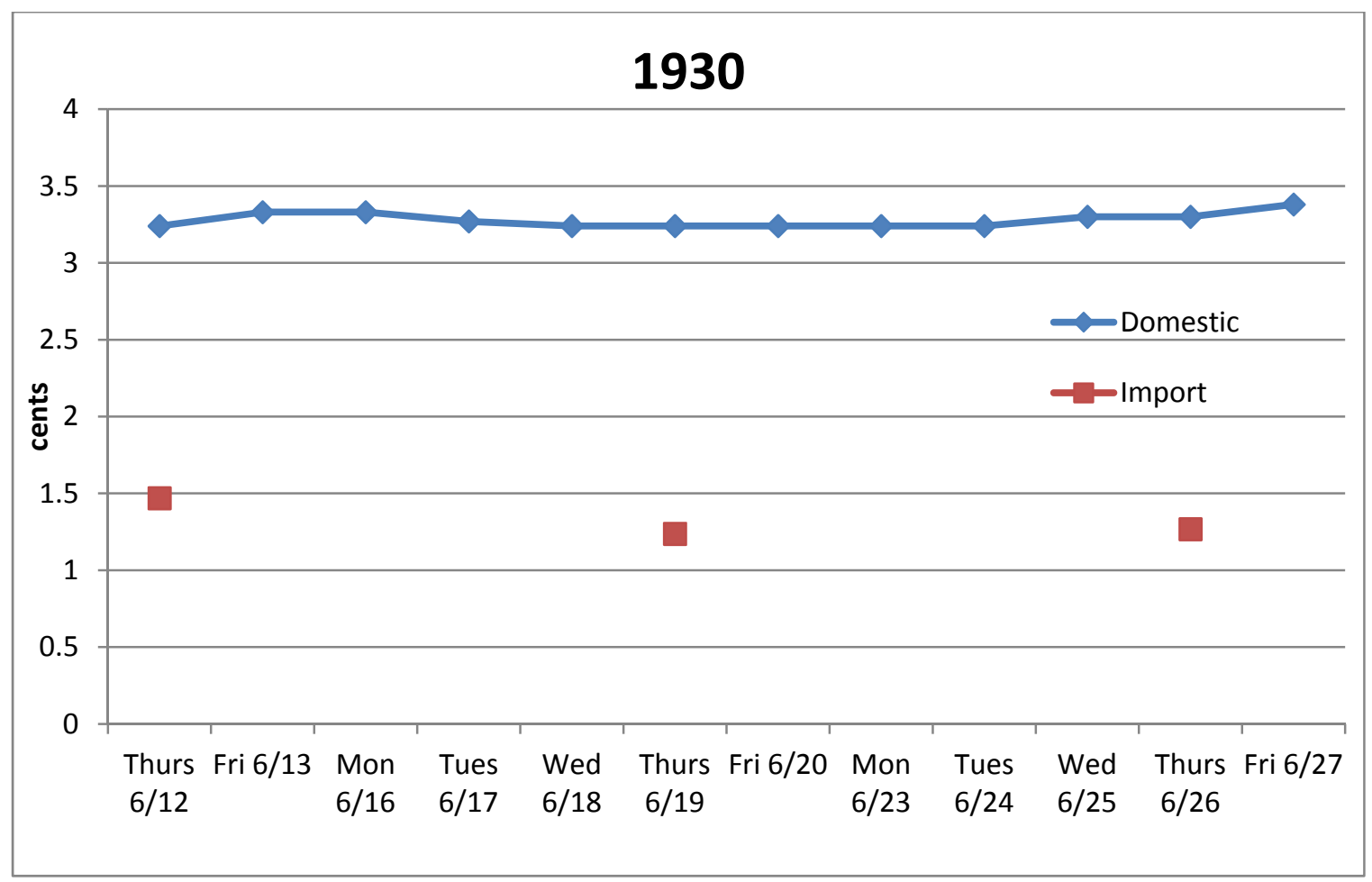

Yet the conclusion that Cuba bore the brunt of the import duties should not come as a surprise, given the nature of the preferential tariff increase. Table 8 shows that there was substantial trade diversion as a result of the 1930 tariff increase. The higher tariff on Cuban sugar (and that from other sources of supply) shifted demand away from those imports and toward imports from the Philippines. In comparison with the first six months of 1930, U.S. imports from Cuba fell 13 percent while imports from the Philippines rose 11 percent. During this era of sharp price deflation, the average price of Cuban sugar fell by a third, but the average price of Philippines sugar fell by 11 percent. Because this tariff increase was not uniform across import suppliers and resulted in significant trade diversion, the adverse effect of the tariff on Cuba's export price (and the improvement in the Philippine export price) is not a surprise. 
Figure 8: Pre- and Post-Tariff Change in Volume and Prices of Sugar, 1930

\begin{tabular}{|l|c|c|c|c|}
\hline & \multicolumn{2}{|c|}{$\begin{array}{c}\text { Imports } \\
\text { (billions of pounds) } \\
\text { (import share in parenthesis) }\end{array}$} & \multicolumn{2}{c|}{$\begin{array}{c}\text { Average import price } \\
\text { (per pound) }\end{array}$} \\
\hline & Cuba & Philippines & Cuba & Philippines \\
\hline Pre-Tariff & 5.52 & 1.56 & 1.8 cents & 3.4 cents \\
\hline Post Tariff & $(77 \%)$ & $(22 \%)$ & & 3.0 cents \\
& $(74 \%)$ & $(27 \%)$ & 1.2 cents & $-11 \%$ \\
\hline Percentage Change & $-12.8 \%$ & $+10.5 \%$ & $-33 \%$ & \\
\hline
\end{tabular}

Note: Comparison is six months before and after tariff change (June 1930).

Source: Commerce and Navigation of the United States, 1931.

\section{Conclusion}

This paper seeks to bring new evidence on the age old question of "who pays the tariff?," a question for which there is surprisingly little empirical evidence. By looking at some of the biggest tariff shocks in American history, in relation to a commodity in which the United States was a large purchaser, we have an opportunity to see whether the United States was able to act as a "large country" and shift some of the burden of its tariff onto its trading partners.

This paper uncovers evidence of an interesting asymmetry: while tariff reductions are passed on wholly to domestic consumers, the burden of tariff increases seems to be split between domestic consumers and foreign producers. The apparent explanation for this asymmetric price response is an asymmetric demand response: in advance of a tariff increase, imports surge and then collapse when the tariff takes effect, whereas imports do not slump before and surge after a 
tariff reduction. This implies that even potentially large countries need not fear an adverse terms-of-trade effect from a unilateral tariff reduction, although they might be able to improve their terms of trade by unilaterally imposing higher tariffs on imports (Bagwell and Staiger 2010). 


\section{References}

Bagwell, Kyle, and Robert W. Staiger. 2010. "The WTO: Theory and Practice.” Annual Review of Economics 2, 223-56.

Besley, Timothy J., and Harvey S. Rosen. 1999. "Sales Taxes and Prices: An Empirical Analysis." National Tax Journal 52, 157-78.

Bickerdike, Charles F. 1906. “The Theory of Incipient Taxes.” Economic Journal 16, 529-35.

Borenstein, Severin, A. Colin Cameron, and Richard Gilbert. 1997. "Do Gasoline Prices Respond Asymmetrically to Crude Oil Price Changes? Quarterly Journal of Economics 112, 305-339.

Broda, Christian, Nuno Limão, and David Weinstein. 2008. "Optimal Tariffs: The Evidence.” American Economic Review 98, 2032-2065.

Chang, W., and L. Alan Winters. 2002. "How Regional Blocs Affect Excluded Countries: The Price Effects of Mercosur." American Economic Review 92, 889-904.

Dye, Alan. 1998. Cuban Sugar in the Age of Mass Production: Technology and the Economics of the Sugar Central, 1899-1929. Stanford: Stanford University Press.

Dye, Alan. 2012. "Creative Destruction and Entrepreneurial Obstruction: Cuban Sugar, 18981939.” Working paper, Barnard College, Columbia University.

Ellison, Sara Fisher, and Wallace P. Mullin. 1995. "Economics and Politics: The Case of Sugar Tariff Reform." Journal of Law and Economics 38, 335-366.

Feenstra, Robert. C. 1989. "Symmetric Pass-Through of Tariffs and Exchange Rates under Imperfect Competition." Journal of International Economics 27, 25-45.

Feenstra, Robert. C. 1995. "Estimating the Effects of Trade Policy." In Handbook of International Economics, Vol. 3, edited by G. M . Grossman and K. Rogoff. Amsterdam: North Holland.

Genesove, David, and Wallace P. Mullin. 1998. "Testing Static Oligopoly Models: Conduct and Cost in the Sugar Industry, 1890-1914." RAND Journal of Economics 29, 355-377.

Irwin, Douglas A. 1997. "Higher Tariffs, Lower Revenues? Analyzing the Fiscal Aspects of the 'Great Tariff Debate of 1888,'” Journal of Economic History 58, 59-72.

Kreinin, Mordechai E. 1961. "Effect of Tariff Changes on the Prices and Volume of Imports." American Economic Review 51, 310-24. 
Ludema, Rodney D., and Anna Maria Mayda. 2014. "Do Terms of Trade Effects Matter for Trade Agreements? Theory and Evidence from WTO Countries." Quarterly Journal of Economics, forthcoming.

Magee, Christopher P., and Stephen P. Magee. 2008. "The United States is a Small Country in World Trade." Review of International Economics 16, 990-1004.

Marion, Justin, and Erich Muehlegger. 2011. "Fuel Tax Incidence and Supply Conditions." Journal of Public Economics 95, 1202-1212.

Miron, Jeffrey A., and Christina D. Romer. 1990. “A New Monthly Index of Industrial Production, 1884-1940.” Journal of Economic History 50, 321-337.

Nakamura, Emi, and Dawit Zerom. 2010. “Accounting for Incomplete Pass-Through.” Review of Economic Studies 77, 1192-1230.

Nicita, Alessandro, Marcelo Olarreaga, and Peri Silva. 2014. "Cooperation in WTO's Tariff Waters." Working paper, UNCTAD and University of Geneva.

Poterba, James M. 1996. "Retail Price Reactions to Changes in State and Local Sales Taxes." National Tax Journal 49, 165-176.

Winkelmann, Liliana, and Rainer Winkelmann. 1998. "Tariffs, Quotas and Terms-of-Trade: The Case of New Zealand.” Journal of International Economics 46, 313-332. 